\title{
Two Novel Eremophilane Sesquiterpenes from an Endophytic Xylariaceous Fungus Isolated from Leaves of Cupressus lusitanica
}

\author{
Luciana S. Amaral and Edson Rodrigues-Filho* \\ Departamento de Química, Universidade Federal de São Carlos, CP 676, \\ 13565-905 São Carlos-SP, Brazil
}

\begin{abstract}
Dois novos sesquiterpenos eremofilanos, cupressolideo A e cupressolideo B, além de dois outros conhecidos, foram isolados a partir do extrato AcOEt do meio de cultura de uma espécie de Xylaria, isolada como fungo endofítico dos tecidos sadios das folhas de Cupressus lusitanica. Estudos espectroscópicos, usando EM e RMN, levaram às estruturas dos dois sesquiterpenos de esqueleto eremofilanos, novos na literatura.
\end{abstract}

Two new eremophilane sesquiterpenes, cupressolide A and cupressolide B, along with two known sesquiterpenes, has been characterized from the EtOAc extract of a liquid medium where a Xylariaceous fungus, isolated as an endophytic fungus from health tissues of Cupressus lusitanica leaves, was cultivated. The structures of the isolated compounds were determined by analyses of their MS and NMR spectroscopic data.

Keywords: Cupressus lusitanica, Xylaria, eremophilane sesquiterpenes, endophytic fungi

\section{Introduction}

Cupressus lusitanica, commonly known as a Mexican Cypress and Portuguese Cypress, belongs to the family Cupressaceae and is usually cultivated as an ornamental tree and in commercial forestry plantation. ${ }^{1,2}$ Due to its economic importance, this plant was included in our continuous program established to study the chemistry and biochemistry aspects of plant microorganisms interactions, with emphasis on those apparently symbiotic associations.

Among the endophytic fungi isolated from healthy tissues of $C$. lusitanica leaves, we obtained some strains with macro and micro morphology characteristics of those microorganisms belonging to the genus Xylaria. Besides these morphologic characteristics, Xylaria species are producers of secondary metabolites, including isocoumarin, ${ }^{3,4}$ cytochalasins, ${ }^{4-6}$ xanthones, ${ }^{7}$ xyloketals, ${ }^{8-10}$ sesquiterpenes, ${ }^{11}$ that contribute to their classification in this genus. In our study we detected isocoumarins and cytochalasins in the fungus extracts using mass spectrometry, which reinforce the hypothesis of its classification as a Xylareaceous fungus. Among the compounds isolated from the fungus extract, two novel (1 and 2) and two known $(\mathbf{3}$ and $\mathbf{4})$ eremophilane sesquiterpenes were identified.

\footnotetext{
*e-mail: edson@dq.ufscar.br
}

The production of these terpenoids corroborated to classify the fungus within Xylariaceae family. Although it is not clear the importance of these compounds as phytotoxic agents, some members of this class of substances have shown remarkable biological activities, such as antiinflammatory, antihyperglycemic, cytotoxic, HIV-1 integrase inhibitory. ${ }^{12-15}$

\section{Results and Discussion}

The EtOAc extract of liquid medium from endophytic fungi was chromatographed on silica gel columns to give four compounds (1-4). Compounds 3 and $\mathbf{4}$ were previously reported in the literature. ${ }^{16,17}$

Compound 1 was obtained as a colorless crystal. The IR spectrum displayed a broad band at $3487 \mathrm{~cm}^{-1}$ characteristic of a hydroxyl group and a band at $1745 \mathrm{~cm}^{-1}$ attributed to a conjugated $\gamma$-lactone. The ${ }^{13} \mathrm{C}$ NMR spectrum exhibited 15 signals which were assigned, by DEPT 135 and HSQC experiments to three methyls, three methylenes, four methines and three $\mathrm{sp}^{2}$ carbons, one of this being a carbonyl group. Its ESI-MS spectrum contains an ion peak of $[\mathrm{M}+\mathrm{H}]^{+}$at $\mathrm{m} / \mathrm{z} 265$, consistent with the molecular formula $\mathrm{C}_{15} \mathrm{H}_{20} \mathrm{O}_{4}$ which also was in accordance with the NMR data. The ${ }^{1} \mathrm{H}$ NMR spectrum of $\mathbf{1}$ showed three signals $\delta_{\mathrm{H}} 1.85,0.83$ and 0.96 attributed to $\mathrm{CH}_{3}-13$, 
$\mathrm{CH}_{3}-14$ and $\mathrm{CH}_{3}-15$, respectively. ${ }^{1} \mathrm{H}$ NMR spectrum exhibited the presence of a deshielded signal assignable to an oxymethine hydrogen at $\delta_{\mathrm{H}} 3.48(1 \mathrm{H}, \mathrm{m}, \mathrm{H}-3)$; this signal correlated in COSY spectrum with the $\delta_{\mathrm{H}} 1.89$ $(1 \mathrm{H}, \mathrm{m}, \mathrm{H}-2 \mathrm{~b}) ; 2.44$ (1H, ddd, J 15.2; 8.4; $4.4 \mathrm{~Hz}, \mathrm{H}-2 \mathrm{a})$; $1.81(1 \mathrm{H}, \mathrm{m}, \mathrm{H}-4)$. $\mathrm{H}-4$ showed coupling with the methyl group at $\delta_{\mathrm{H}} 0.96\left(3 \mathrm{H}, J 6.8 \mathrm{~Hz}, \mathrm{CH}_{3}-15\right)$. The presence of an epoxy group was confirmed by the chemical shifts of $\mathrm{H}-1(\delta 3.06), \mathrm{C}-1(\delta 58.5)$, and $\mathrm{C}-10(\delta 63.2)$.

The COSY spectrum exhibited correlation peaks among the oxymethine hydrogen at $\delta_{\mathrm{H}} 4.9(1 \mathrm{H}, \mathrm{m}, \mathrm{H}-8)$ with hydrogens at $\delta_{\mathrm{H}} 2.05(1 \mathrm{H}, \mathrm{m}, \mathrm{H}-9 \mathrm{a}) ; 1.82(1 \mathrm{H}, \mathrm{m}, \mathrm{H}-9 \mathrm{~b})$; $1.85\left(3 \mathrm{H}, \mathrm{t}, J 1.2 \mathrm{~Hz}, \mathrm{CH}_{3}-13\right)$.

HSQC analysis indicated the presence of one tetrasubstituted double bond which was associated with the carbons at $\delta_{\mathrm{C}} 159.5 ; 122.3$ (C-7 and C-11, respectively). On the other hand another double bond was observed in the ${ }^{13} \mathrm{C}$ NMR spectrum, with characteristic chemical shifts of a carbonyl group at $\delta_{\mathrm{C}} 174.6$ attributed to $\mathrm{C}-12$.

The HSQC spectrum exhibited correlations among the diasterotopic hydrogens at $\delta_{\mathrm{H}} 2.23(1 \mathrm{H}$, br d, $J 13.6 \mathrm{~Hz}$, $\mathrm{H}-6 \mathrm{~b})$ and $\delta_{\mathrm{H}} 2.76(1 \mathrm{H}, \mathrm{d}, J 13.6 \mathrm{~Hz}, \mathrm{H}-6 \mathrm{~b})$ with the carbon at $\delta_{\mathrm{C}} 35.1$. The HMBC spectrum showed coupling of H-6b with $\mathrm{C}-5, \mathrm{C}-7, \mathrm{C}-8, \mathrm{C}-10, \mathrm{C}-11$ and $\mathrm{CH}_{3}-14$. The $\mathrm{COSY}$ and $\mathrm{HMBC}$ analysis of $\mathbf{1}$ led to a partial structure as shown in Figure 1.

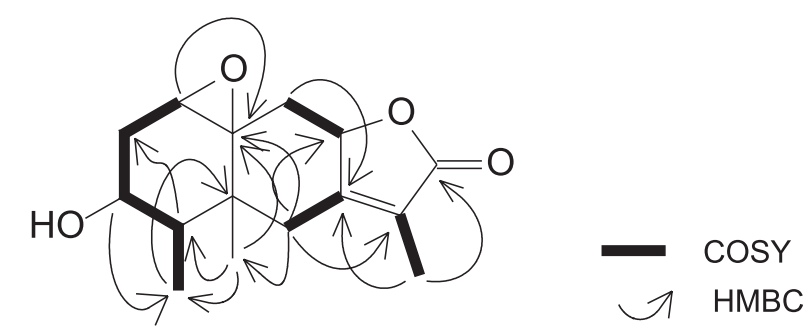

Figure 1. Selected H-H COSY and HMBC correlations for compound 1.

The relative stereochemistry of $\mathbf{1}$ was elucidated using nOe and COSY spectroscopy. The $\beta$ orientation of H-3 was inferred from the nOe correlation with $\mathrm{CH}_{3}-14$ and $\mathrm{CH}_{3}-15$. H-8 ( $\left.\delta 4.90\right)$ should be $\alpha$ oriented as indicated by the homoallylic coupling with the methyl $\left(\mathrm{CH}_{3}-13, \delta 1.85\right)$ bounded to $\mathrm{C}-11$ observed in the COSY experiment. This homoallylic coupling requires a $90^{\circ}$ dihedral angle of the methyl group at C-11 with $\mathrm{H}-6 \alpha$ and $\mathrm{H}-8$, witch was in agreement with the nOe experiment. Furthermore, the nOe spectrum showed correlations of $\mathrm{H}-6 \alpha$ with $\mathrm{H}-4\left(\begin{array}{l}\delta \\ 1.81\end{array}\right)$ and of $\mathrm{H}-6 \beta$ with $\mathrm{CH}_{3}-13, \mathrm{CH}_{3}-14$ and $\mathrm{CH}_{3}-15$. All NMR data are shown in the Table 1.

Compound $\mathbf{2}$ showed spectroscopic data very similar to those of $\mathbf{1}$, indicating the presence of an eremophilane skeleton. The IR spectrum displayed a broad band at $3508 \mathrm{~cm}^{-1}$ characteristic of a hydroxyl group. The

Table 1. NMR spectroscopy data for eremophilane sesquiterpene $\mathbf{1}^{\text {a }}$

\begin{tabular}{lllll}
\hline Position & $\delta_{\mathrm{H}}, \mathrm{mult},(\mathrm{J}$ in Hz) & $\delta_{\mathrm{C}}$ & $\mathrm{COSY}$ & $\mathrm{HMBC}(\mathrm{H} \rightarrow \mathrm{C})$ \\
\hline 1 & $3.06, \mathrm{~d}(4.4)$ & 58.5 & $\mathrm{H} 2 \mathrm{a}$ & $\mathrm{C} 2, \mathrm{C} 10$ \\
$2 \mathrm{a}$ & $2.44, \mathrm{ddd}(4.4 ; 8.4 ; 15.2)$ & 33.0 & $\mathrm{H} 1, \mathrm{H} 2 \mathrm{~b}, \mathrm{H} 3$ & $\mathrm{C} 3, \mathrm{C} 14$ \\
$2 \mathrm{~b}$ & $1.89, \mathrm{~m}$ & & $\mathrm{H} 2 \mathrm{a}, \mathrm{H} 3$ & $\mathrm{C} 1, \mathrm{C} 10, \mathrm{C} 3$ \\
3 & $3.48, \mathrm{~m}$ & 67.4 & $\mathrm{H} 2 \mathrm{a}, \mathrm{H} 2 \mathrm{~b}, \mathrm{H} 4$ & $\mathrm{C} 4, \mathrm{C} 15$ \\
4 & $1.81, \mathrm{~m}$ & 40.7 & $\mathrm{H} 15, \mathrm{H} 3$ & $\mathrm{C} 2, \mathrm{C} 3$ \\
5 & - & 39.1 & - & - \\
$6 \mathrm{a}$ & $2.23, \mathrm{brd}(13.6)$ & 35.1 & $\mathrm{H} 6-\mathrm{b}, \mathrm{H} 13, \mathrm{H} 14$ & $\mathrm{C} 5, \mathrm{C} 7, \mathrm{C} 8, \mathrm{C} 10, \mathrm{C} 11, \mathrm{C} 14$ \\
$6 \mathrm{~b}$ & $2.76, \mathrm{~d}(13.6)$ & & $\mathrm{H} 6 \mathrm{a}$ & $\mathrm{C} 5, \mathrm{C} 7, \mathrm{C} 8, \mathrm{C} 10, \mathrm{C} 11, \mathrm{C} 14$ \\
7 & - & 159.5 & - & $\mathrm{n} . \mathrm{d}$ \\
8 & $4.90, \mathrm{~m}$ & 78.3 & $\mathrm{H} 9 \mathrm{a}, \mathrm{H} 9 \mathrm{~b}, \mathrm{H} 13$ & $\mathrm{n} . \mathrm{d}$. \\
$9 \mathrm{a}$ & $2.05, \mathrm{~m}$ & 38.0 & $\mathrm{H} 9 \mathrm{~b}, \mathrm{H} 8$ & $\mathrm{C} 7, \mathrm{C} 8, \mathrm{C} 13$ \\
$9 \mathrm{~b}$ & $1.82, \mathrm{~m}$ & & $\mathrm{H} 9 \mathrm{a}, \mathrm{H} 8$ & $\mathrm{C} 3, \mathrm{C} 5, \mathrm{C} 14, \mathrm{C} 15$ \\
10 & - & 63.2 & - & - \\
11 & - & 122.3 & - & - \\
12 & - & 174.6 & - & - \\
13 & $1.85, \mathrm{t}(1.2)$ & 15.8 & $\mathrm{H} 6 \mathrm{~b}, \mathrm{H} 8, \mathrm{H} 15$ & $\mathrm{C} 7, \mathrm{C} 11, \mathrm{C} 12, \mathrm{C} 15$ \\
14 & $0.83, \mathrm{~d}(1.0)$ & 10.1 & $\mathrm{H} 6 \mathrm{~b}$ & $\mathrm{C} 4, \mathrm{C} 5, \mathrm{C} 6, \mathrm{C} 10, \mathrm{C} 15$ \\
15 & $0.96, \mathrm{~d}(6.8)$ & $\mathrm{C} 3, \mathrm{C} 4, \mathrm{C} 5$ \\
\hline
\end{tabular}

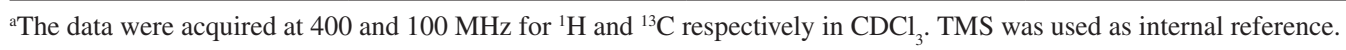


${ }^{1} \mathrm{H}$ NMR experiment exhibited two olefinic hydrogens, three carbinolic hydrogens and two methyl groups. The EI-MS spectrum of 2 contains an ion peak of $\mathbf{M}^{+}$at $\mathrm{m} / \mathrm{z}$ 252 , consistent with the molecular formula $\mathrm{C}_{15} \mathrm{H}_{24} \mathrm{O}_{3}$ and the data observed in the NMR spectrum. The ${ }^{1} \mathrm{H}$ NMR spectrum of compound $\mathbf{2}$ exhibited deshielded signals due the presence of olefinic hydrogens at $\delta_{\mathrm{H}} 5.26(1 \mathrm{H}, \mathrm{d}, J$ $0.8 \mathrm{~Hz}, \mathrm{H}-12 \mathrm{a})$ and $\delta_{\mathrm{H}} 5.12(1 \mathrm{H}, \mathrm{d}, J 0.8 \mathrm{~Hz} \mathrm{H}-12 \mathrm{~b})$. The COSY spectrum showed the coupling of $\mathrm{H}-12 \mathrm{a}$ with the carbinolic hydrogens at $\delta_{\mathrm{H}} 4.19(1 \mathrm{H}, \mathrm{dd}, J 11.2 ; 0.8 \mathrm{~Hz}$, $\mathrm{H}-13 \mathrm{a})$ and $\delta_{\mathrm{H}} 4.16(1 \mathrm{H}, \mathrm{dd}, J 11.2 ; 0.8 \mathrm{~Hz}, \mathrm{H}-13 \mathrm{~b})$. The peak attributed to $\mathrm{H}-8$ at $\delta_{\mathrm{H}} 3.88(1 \mathrm{H}$, ddd, $J 4.4 ; 10.0$; $15.6 \mathrm{~Hz}$ ) exhibited correlations in the COSY spectrum with the hydrogens at $\delta_{\mathrm{H}} 2.43(1 \mathrm{H}, \mathrm{ddd}, J 4.4 ; 8.0 ; 13.2 \mathrm{~Hz}, \mathrm{H}-7)$, $\delta_{\mathrm{H}} 2.18(1 \mathrm{H}, \mathrm{dd}, J 10.0 ; 12.4 \mathrm{H}-9 \mathrm{a})$ and $\delta_{\mathrm{H}} 1.38(1 \mathrm{H}, \mathrm{m}$, $\mathrm{H}-9 \mathrm{~b})$.

The presence of a methine group at $\delta_{\mathrm{H}} 1.71(1 \mathrm{H}, \mathrm{m}$, $\mathrm{H}-4)$ was confirmed by COSY correlations at $\delta_{\mathrm{H}} 1.21(1 \mathrm{H}$, $\mathrm{m}, \mathrm{H}-3 \mathrm{a})$ and $\delta_{\mathrm{H}} 1.71(1 \mathrm{H}, \mathrm{m}, \mathrm{H}-3 \mathrm{~b})$ and $\delta_{\mathrm{H}} 0.71(3 \mathrm{H}, \mathrm{d}, J$ $\left.5.6 \mathrm{~Hz}, \mathrm{CH}_{3}-15\right)$. The signal of $\mathrm{CH}_{2}-13(\delta 4.16$ and 4.19$)$, $\mathrm{CH}_{3}-14(\delta 1.02), \mathrm{CH}_{3}-15(\delta 0.71)$ and $\mathrm{CH}_{2}-12$ ( $\delta 5.12$ and $5.26)$ in the ${ }^{1} \mathrm{H}$ NMR spectrum were in agreement with the profile of an eremophilane with a double bound at C-11 and $\mathrm{C}-12$. The epoxide group at C-1 and C-10 was deduced from the chemical shifts of $\mathrm{H}-1$ ( $\delta 2.97), \mathrm{C}-1$ ( $\delta 59.7)$, and

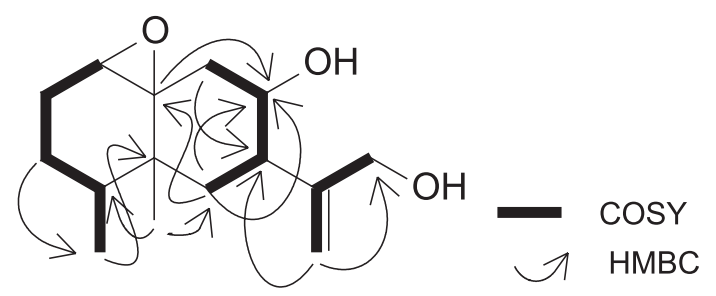

Figure 2. Selected H-H COSY and HMBC correlations for compound 2.

C-10 ( $\delta$ 65.8). The COSY analysis of 2 led to a partial structure as shown by bold-faced lines in Figure 2, which were supported by HMBC correlations (Table 2). The relative stereochemistry was based on those determined to compound 2. All NMR data can be observed in Table 2 .

\section{Conclusions}

The genus Xylaria is known for being a rich source of structurally diverse natural products including isocoumarin,, 3 cytochalsins, ${ }^{4-6}$ xyloketals, ${ }^{8-10}$ sesquiterpenes ${ }^{11}$ and others. Among these compounds eremophilane sesquiterpenes stand out for several biological activities. ${ }^{12-15}$ One member of this genus reported in the present study showed the notable ability to produce eremophilane sesquiterpenes, including two new in the literature, cupressolide A and cupressolide B. Due to the many biological activities shown

Table 2. NMR spectroscopy data for eremophilane sesquiterpene $\mathbf{2}^{\text {a }}$

\begin{tabular}{|c|c|c|c|c|}
\hline Position & $\delta_{\mathrm{H}}$, mult, $(J$ in $\mathrm{Hz})$ & $\delta_{\mathrm{c}}$ & COSY & $\operatorname{HMBC}(\mathrm{H} \rightarrow \mathrm{C})$ \\
\hline 1 & 2.97, d (6.8) & 59.7 & $\mathrm{H} 2 \mathrm{a} / \mathrm{b}$ & n.d. \\
\hline $2 \mathrm{a} / 2 \mathrm{~b}$ & $1.91, \mathrm{~m}$ & 22.1 & $\mathrm{H} 1, \mathrm{H} 3 \mathrm{a} / \mathrm{b}$ & n.d. \\
\hline $3 a / 3 b$ & $1.21, \mathrm{~m}$ & 24.3 & $\mathrm{H} 2 \mathrm{a} / \mathrm{b}, \mathrm{H} 4$ & $\mathrm{C} 15$ \\
\hline 4 & $1.71, \mathrm{~m}$ & 33.1 & $\mathrm{H} 3 \mathrm{a} / \mathrm{b}, \mathrm{H} 15$ & n.d. \\
\hline 5 & - & 35.8 & - & $\mathrm{C} 4, \mathrm{C} 15$ \\
\hline $6 a$ & $1.68, \mathrm{~m}$ & 39.6 & $\mathrm{H} 6 \mathrm{~b}, \mathrm{H} 7$ & $\mathrm{C} 7, \mathrm{C} 8$ \\
\hline $6 b$ & $1.41, \mathrm{~m}$ & & H6a, H7, H8 & $\mathrm{C} 7, \mathrm{C} 8, \mathrm{C} 10$ \\
\hline 7 & $2.43, \mathrm{ddd},(4.4 ; 8.0 ; 13.2)$ & 45.4 & H6a, H6b, H8, & n.d. \\
\hline 8 & 3.88, ddd $(4.4 ; 10.0 ; 15.6)$ & 71.6 & $\mathrm{H} 6 \mathrm{~b}, \mathrm{H} 7, \mathrm{H} 9 \mathrm{a} / \mathrm{b}$ & n.d. \\
\hline $9 \mathrm{a}$ & $2.18, \mathrm{dd}(10.0 ; 12.4)$ & 38.5 & $\mathrm{H} 8, \mathrm{H} 9 \mathrm{~b}$ & $\mathrm{C} 8$ \\
\hline $9 b$ & $1.38(\mathrm{~m}, 1 \mathrm{H})$ & & $\mathrm{H} 9 \mathrm{a}$ & $\mathrm{C} 7, \mathrm{C} 8, \mathrm{C} 10$ \\
\hline 10 & - & 65.8 & - & - \\
\hline 11 & - & 150.1 & - & - \\
\hline $12 \mathrm{a}$ & $5.26, \mathrm{~d}(0.8)$ & 113.2 & 12b, H13a, H13b & $\mathrm{C} 7, \mathrm{C} 13$ \\
\hline $12 b$ & $5.12, \mathrm{~d}(0.8)$ & & $\mathrm{H} 12 \mathrm{a}$ & $\mathrm{C} 7, \mathrm{C} 13$ \\
\hline $13 \mathrm{a}$ & $4.19, \mathrm{dd}(11.2 ; 0.8)$ & 65.8 & $\mathrm{H} 12 \mathrm{a}$ & $\mathrm{C} 7, \mathrm{C} 11, \mathrm{C} 12$ \\
\hline $13 b$ & $4.16, \mathrm{dd}(11.2 ; 0.8)$ & & $\mathrm{H} 12 \mathrm{a}$ & $\mathrm{C} 7, \mathrm{C} 11, \mathrm{C} 12$ \\
\hline 14 & $1.02, \mathrm{~s}$ & 15.9 & n.d. & $\mathrm{C} 4, \mathrm{C} 5, \mathrm{C} 6,10$ \\
\hline 15 & $0.71, \mathrm{~d}(5.6)$ & 14.8 & $\mathrm{H} 4$ & $\mathrm{C} 3, \mathrm{C} 4, \mathrm{C} 5$ \\
\hline
\end{tabular}

${ }^{a}$ The data were acquired at 400 and $100 \mathrm{MHz}$ for ${ }^{1} \mathrm{H}$ and ${ }^{13} \mathrm{C}$ respectively in $\mathrm{CDCl}_{3}$. TMS was used as internal reference. 


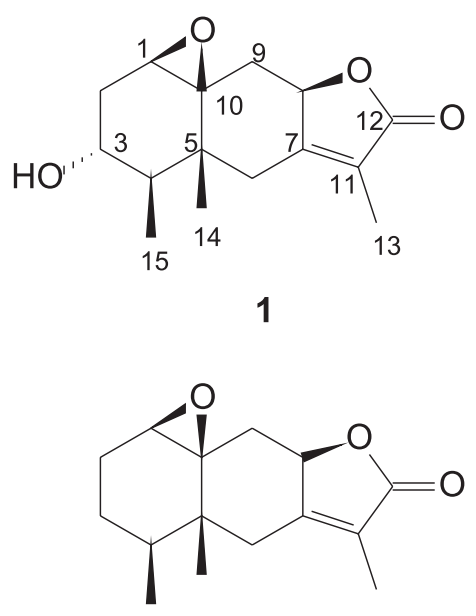

3
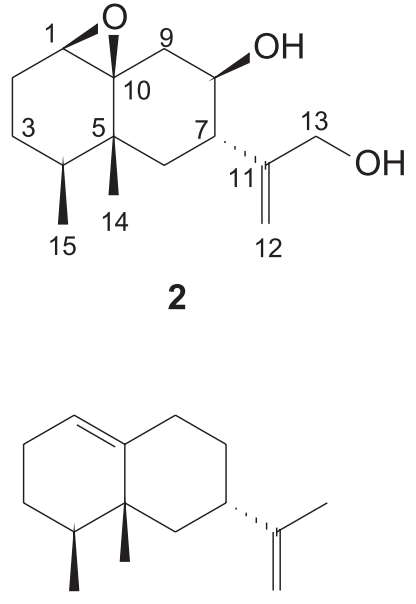

4

Figure 3. Eremophilane sesquiterpenes produced by Xylaria sp., an endophytic fungus isolated from Cupressus lusitanica leaves.

by this class of compounds, this Xylaria deserves a careful study aiming to sesquiterpene production enhancement.

\section{Experimental}

\section{Equipment}

IR spectra were run on a Bomen MB102 -IR spectrometer using $\mathrm{KBr}$ pellets. Optical rotation was measured on a PerkinElmer 241 polarimeter. GC/MS analyses were performed using GC 8000 series Fisons and VG Platform mass spectrometer detector. 1D and 2D NMR spectra were obtained in $\mathrm{CDCl}_{3}$ (Aldrich) on DRX 400 Bruker spectrometer operating at $400 \mathrm{MHz}$ for hydrogen and $100 \mathrm{MHz}$ for ${ }^{13} \mathrm{C}$ and TMS was used as internal standard. MS were acquired in positive ion mode on a triple quadrupole Micromass Quattro LC spectrometer, equipped with an ESI ion source.

\section{Plant material}

Health leaves of Cupressus lusitanica were collected in São Carlos, São Paulo State, Brazil. A voucher specimen (No. 7281) has been deposited in the Herbarium of the Botanic Department of Universidade Federal de São Carlos, Brazil.

\section{Fungal material}

The method of surface sterilization employed in this work was similar to that used by Petrini et al. ${ }^{18}$ After the collection, the leaves were washed in abundant water (domestic use grade) and then in distilled water. The leaves were surface sterilization by consecutive immersion in $70 \%$ ethanol (2 s), sterile distilled water $(2 \mathrm{~s}), 11 \%$ aqueous sodium hypochloride for 1-5 min and 70\% ethanol (2 s), and then in sterile distilled water. The material was placed in Petri dishes containing PDA medium (potato, dextrose and agar) supplemented with $100 \mu \mathrm{g} \mathrm{mL}^{-1}$ terramicin and incubated at room temperature. Endophytic fungi growing from the plant tissues, were picked and recultured on PDA to determine culture purity. It was deposited at LaBioMMi - Laboratório de Bioquímica Micromolecular de Microorganismos - of the Departamento de Química at Universidade Federal de São Carlos, Brazil. Working stocks were prepared on potato dextrose agar.

\section{Fermentation and extraction}

The fungus was grown under static conditions at room temperature for 20 days in 20 Erlenmeyer flasks containing the liquid medium ( $300 \mathrm{~mL}$ per flask) composed of glucose $\left(26.7 \mathrm{~g} \mathrm{~L}^{-1}\right)$, yeast extract $\left(10.0 \mathrm{~g} \mathrm{~L}^{-1}\right), \mathrm{NaNO}_{3}$ (3.0 g L $\left.\mathrm{g}^{-1}\right), \mathrm{K}_{2} \mathrm{HPO}_{4}\left(1.0 \mathrm{~g} \mathrm{~L}^{-1}\right), \mathrm{MgSO}_{4} \cdot 7 \mathrm{H}_{2} \mathrm{O}\left(0.5 \mathrm{~g} \mathrm{~L}^{-1}\right)$, $\mathrm{KCl}\left(0.5 \mathrm{~g} \mathrm{~L}^{-1}\right), \mathrm{FeSO}_{4} \cdot 7 \mathrm{H}_{2} \mathrm{O}\left(0.01 \mathrm{~g} \mathrm{~L}^{-1}\right)$. The mycelium was separated by reduced pressure filtration and the liquid phase was partitioned with ethyl acetate $(1,000 \mathrm{~mL} \times 3)$. The organic solvent was dried with anydrous sodium sulfate, filtered and removed using vaccum to give the crude extract. Crude extract was analyzed by GC/MS. This technique enabled the detection of the eremophilane sesquiterpene valencene (4). The extract was chromatographed on silica gel columm $(\mathrm{h}=4.5 \mathrm{~cm}$ and $\varnothing=3.7 \mathrm{~cm})$ eluted with a Hex: $\mathrm{CH}_{2} \mathrm{Cl}_{2}$ (1:1); $\mathrm{CH}_{2} \mathrm{Cl}_{2}$ :EtOAc (1:1); $\mathrm{CH}_{2} \mathrm{Cl}_{2}$ :EtOAc (1:4); $\mathrm{CH}_{2} \mathrm{Cl}_{2}$ :EtOAc:MeOH (1:4:10\%); EtOAc:MeOH (1:1); $\mathrm{MeOH}(100 \%)$ to afford six fractions (A-F). The fractions $\mathrm{C}$ and $\mathrm{D}$ were rechromatographed on silica gel columm $(\mathrm{h}=16 \mathrm{~cm}$ and $\varnothing=2.5 \mathrm{~cm})$ with Hexane $100 \%$ gradient to EtOAc:MeOH (1:1) to give $\mathbf{1}(5.2 \mathrm{mg}), \mathbf{2}$ $(4.8 \mathrm{mg}), \mathbf{3}(2.7 \mathrm{mg})$. 


\section{GC/MS analysis}

The extract was submitted to clean-up procedures using solid phase extraction (SPE). The SPE cartridge was activated with $100 \%$ Hexane and conditioned with $3 \mathrm{~mL}$ of $\mathrm{CHCl}_{3}$. The extract $(10 \mathrm{mg})$ was dissolved in $3 \mathrm{~mL}$ of $\mathrm{CHCl}_{3}$ and loaded to the SPE cartridge. Elution of SPE cartridge with $\mathrm{CHCl}_{3}$ produced an apolar fraction. For the GC/MS analysis the injector temperature was kept at $180{ }^{\circ} \mathrm{C}$ and the $\mathrm{GC}$ oven temperature was maintained at $70^{\circ} \mathrm{C}$ during 6 min and then increased to $250{ }^{\circ} \mathrm{C}$ at a rate of $6{ }^{\circ} \mathrm{C} \mathrm{min}{ }^{-1}$ and finally increased to $325^{\circ} \mathrm{C}$ at $3{ }^{\circ} \mathrm{C} \mathrm{min}{ }^{-1}$. The sample volume injected was $2 \mu \mathrm{L}$.

\section{MS data collection}

ESI-MS data were colleted from direct introduction of the sample solution $5 \mu \mathrm{L}$ of compound $\mathbf{1}\left(5 \mu \mathrm{g} \mathrm{mL}^{-1}\right)$. The optimal voltages found for the probe and ion source components to produce maximum intensity of the ions $[\mathrm{M}+\mathrm{H}]^{+}$were $3.3 \mathrm{kV}$ for the capillary, $19 \mathrm{~V}$ for the sample cone, and $4 \mathrm{~V}$ for the extractor cone.

\section{Physical and spectral data}

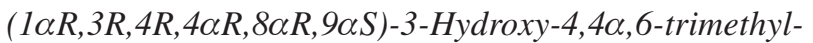
$1 \alpha, 2,3,4,4 \alpha R, 8 \alpha, 9$-octahydro-7H-oxirene [8, $8 \alpha]$ naphtho[2,3ß] furan-7-one, compound 1: Cupressolide A

Colorless crystals $\left(\mathrm{CH}_{2} \mathrm{Cl}_{2}\right) ;[\alpha]_{\mathrm{D}}^{25}=-6.262(c 0.0001$, $\left.\mathrm{CHCl}_{3}\right) ; \mathrm{IR}(\mathrm{KBr}) v_{\max } / \mathrm{cm}^{-1}: 3487,1745 ;$ ESI-MS $m / z 265$ $[\mathrm{M}+\mathrm{H}]^{+}$; ESI-MS-MS (20 eV) m/z 265 (78\%), 247 (17), 229 (39), 201 (50), 183 (100), 173 (70), 147 (60), 119 (55); NMR data see Table 1.

(1 $\alpha R, 4 S, 4 \alpha R, 6 S, 7 R, 8 \alpha S)-6-[1-(H y d r o x y m e t h y l)$ vinyl]-

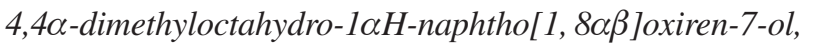
compound 2: Cupressolide B

Colorless crystal $\left(\mathrm{CH}_{2} \mathrm{Cl}_{2}\right) ; \mathrm{IR}(\mathrm{KBr}) v_{\max } / \mathrm{cm}^{-1}: 3508$; EIMS (70 eV) $m / z, 252[\mathrm{M}]^{+}$(3\%), 234 (6), 216 (12), 201 (16), 168 (57), 153 (75), 125 (100); NMR data see Table 2.

\section{Supplementary Information}

Supplementary data are available free of charge at http://jbcs.sbq.org.br, as PDF file.

\section{Acknowledgments}

The autors are gratefull to the Brazilian institutions FAPESP - Fundação de Amparo à Pesquisa do Estado de
São Paulo, CNPq - Conselho Nacional de Desenvolvimento Científico e Tecnológico, CAPES - Coordenação de Aperfeiçoamento de Pessoal de Ensino Superior for the financial support.

\section{References}

1. Farjon, A.; Taxon 1993, 42, 81.

2. Graniti, A.; Annu. Rev. Phytopathol. 1998, 36, 91.

3. Tansuwan, S.; Pornpakakul, S.; Roengsumran, S.; Petsom, A.; Muangsin, N.; Sihanonta, P.; Chaichit N.; J. Nat. Prod. 2007, 10, 1620 .

4. Pongcharoen, W.; Rukachaisrikul, V.; Isaka, M.; Sriklung, K.; Chem. Pharm. Bull. 2007, 55, 1647.

5. Espada, A.; Rivera-Sagredo, A.; de la Fuente, J. M.; HuesoRodríguez, J. A.; Élson, S. W.; Tetrahedron 1997, 53, 6485.

6. Abate, D.; Abraham, W.; Meyer, H.; Phytochemistry 1997, 44, 1443.

7. Healy, P. C.; Hocking, A.; Tran-Dinh, N.; Pitt, J. I.; Shivas, R. G.; Mitchell, J. K.; Kotiw, M.; Davis, R. A.; Phytochemistry 2004, 65, 2373.

8. Lin, Y.; Wu,X.; Feng, S.; Jiang, G.; Luo, J.; Zhou, S.; Vrijmoed, L. L. P.; Jones, E. B. G.; Krohn, K.; Steingröver, K.; Zsila, F.; J. Org. Chem. 2001, 66, 6252.

9. Xiaobo, Z.; Haiying, W.; Linyu, H.; Yongcheng, L.; Zhongtao, L.; Process Biochem. 2006, 41, 293.

10. Liu, X.; Xu, F.; Zhang, Y.; Liu, L.; Huang, H.; Cai, X.; Lin, Y.; Chanb W.; Russ. Chem. Bull. 2006, 55, 1091.

11. McDonald, L. A.; Barbieri, L. R.; Bernan, V. S.; Janso, J.; Lassota, P.; Carter G. T.; J. Nat. Prod. 2004, 67, 1565.

12. Wang, W.; Gao, K.; Jia, Z.; J. Nat. Prod. 2002, 65, 714.

13. Garduño-Ramírez, M. L.; Trejo, A.; Navarro, V.; Bye, R.; Linares, E.; Delgado, G.; J. Nat. Prod. 2001, 64, 432.

14. Li, E.-W.; Pan, J.; Gao, K.; Jia, Z.-J.; Planta Med. 2005, 71, 1140.

15. Zhang, Q. J.; Dou, H.; Zheng, Q. X.; Zhou, C. H.; Xu, Z. J.; Peng, H.; Zhao, Y.; Chin. Chem. Lett. 2005, 16, 360.

16. Zhao Y.; Schenk, D. J.; Takahashi, S.; Chappell, J.; Coates, R. M.; J. Org. Chem. 2004, 69, 7428.

17. Prez-Castorena, A. L.; Arciniegas, A.; Guzmn, S. L.; Villaseor, J. L.; de Vivar, A. R.; J. Nat. Prod. 2006, 69, 1471.

18. Petrini, O.; Sieber, T. N.; Toti, L.; Viret, O.; Natural Toxins 1992, 1,185

Received: June 25, 2009

Web Release Date: March 25, 2010

FAPESP has sponsored the publication of this article. 
Two Novel Eremophilane Sesquiterpenes from an Endophytic Xylariaceous Fungus Isolated from Leaves of Cupressus lusitanica

\section{Luciana S. Amaral and Edson Rodrigues-Filho*}

Departamento de Química, Universidade Federal de São Carlos, CP 676,

13565-905 São Carlos-SP, Brazil

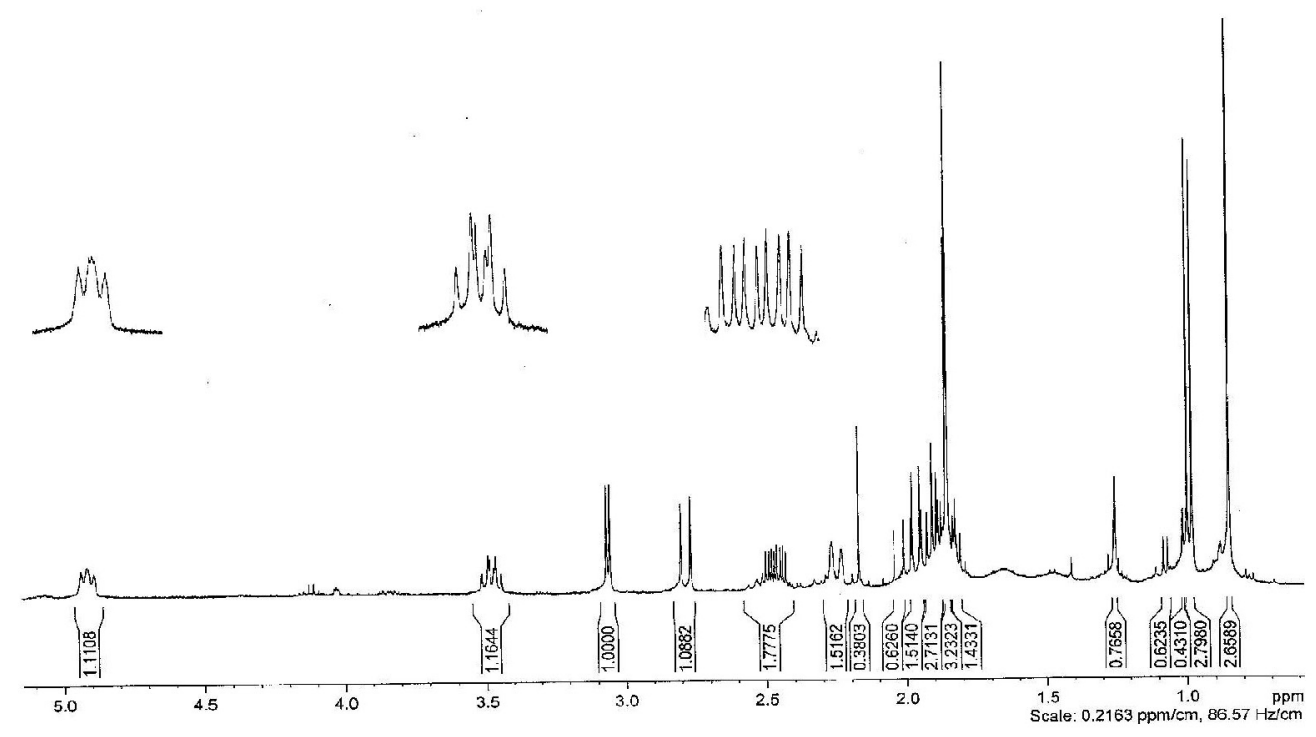

Figure S1. 'H NMR spectrum of compound $1\left(400 \mathrm{MHz}, \mathrm{CDCl}_{3}\right)$. 


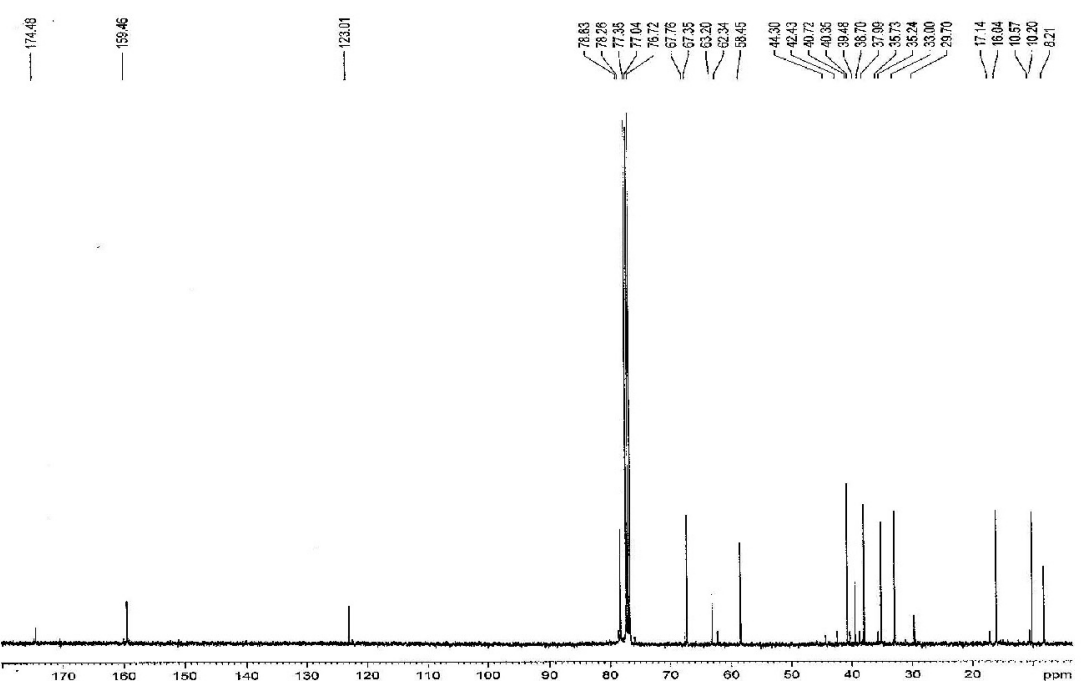

Figure S2. ${ }^{13} \mathrm{C}$ NMR spectrum of compound $\mathbf{1}\left(100 \mathrm{MHz}, \mathrm{CDCl}_{3}\right)$.
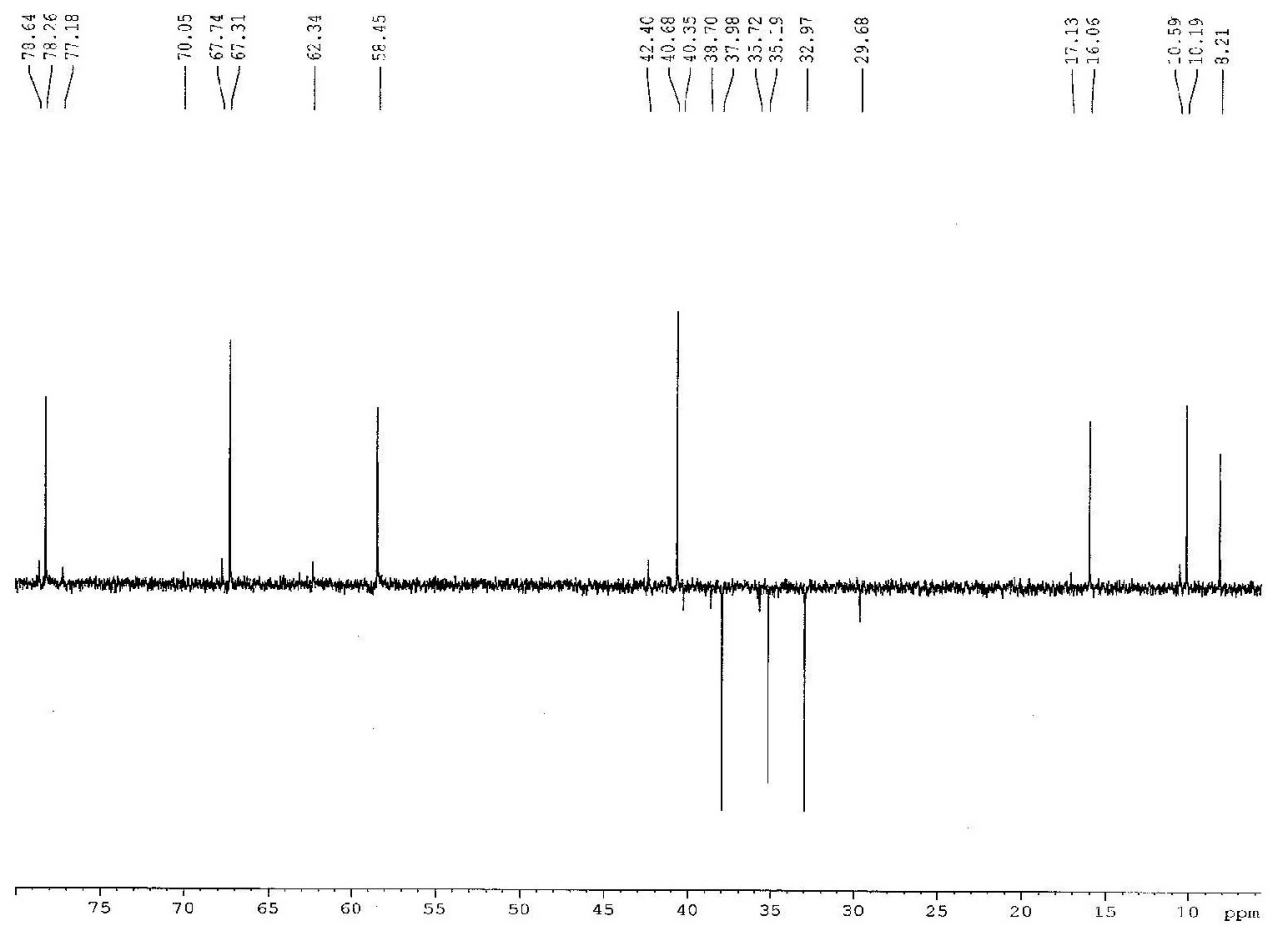

Figure S3. DEPT 135 spectrum of compound $1\left(100 \mathrm{MHz}, \mathrm{CDCl}_{3}\right)$. 


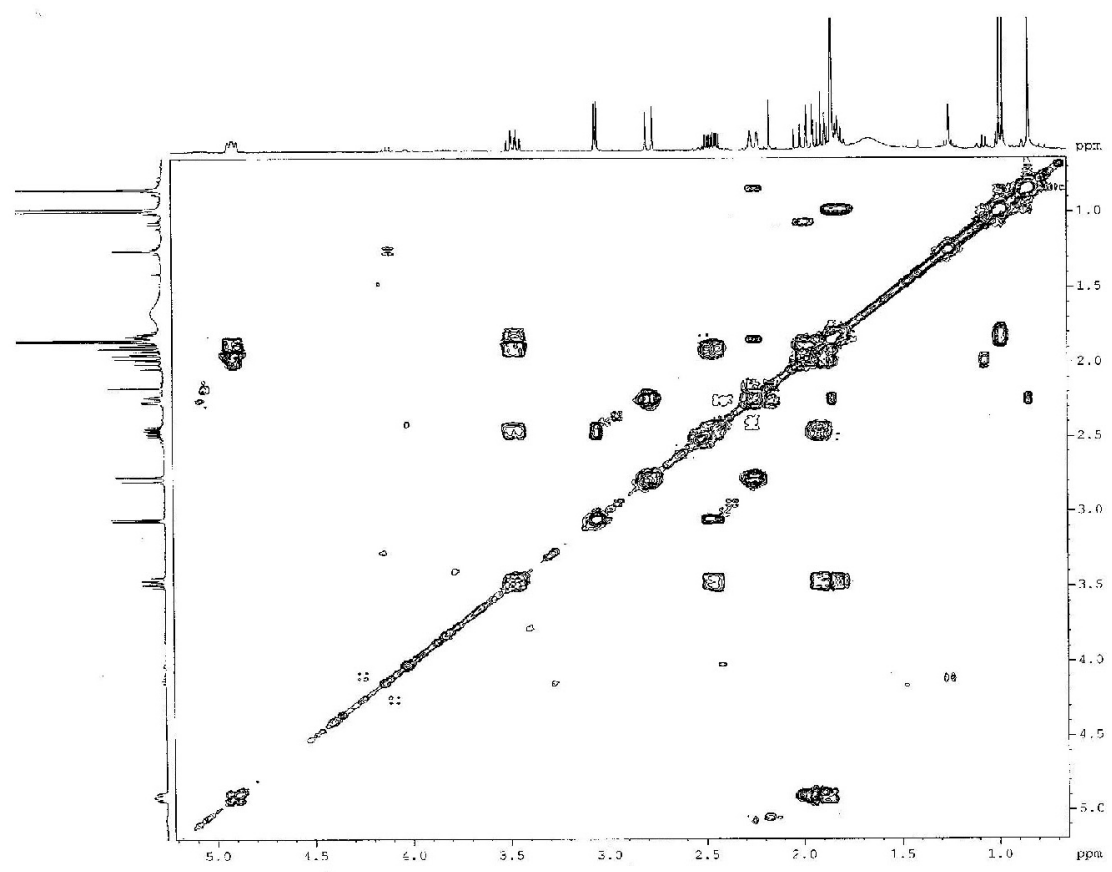

Figure S4. ${ }^{1} \mathrm{H}-{ }^{1} \mathrm{H}$ COSY NMR correlation spectroscopy $2 \mathrm{D}$ NMR spectrum of compound $\mathbf{1}\left(400 \mathrm{MHz}, \mathrm{CDCl}_{3}\right)$.

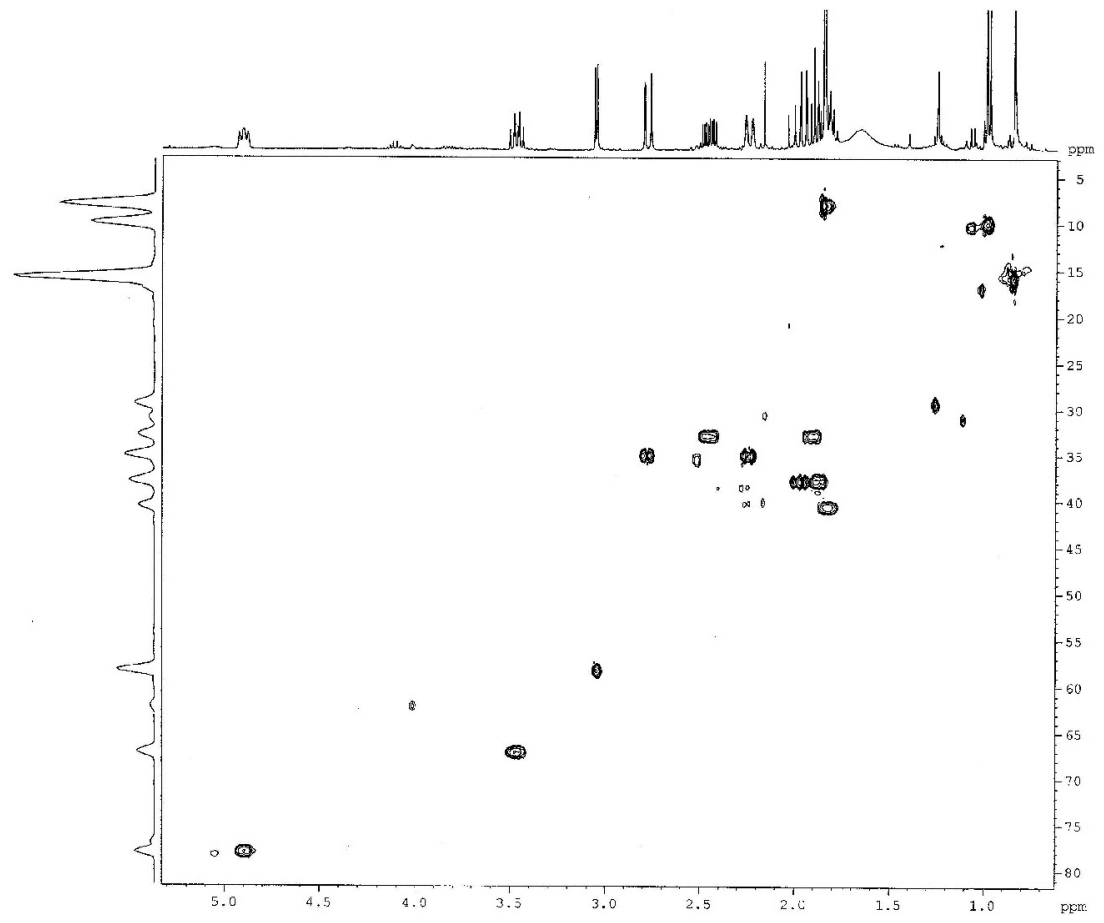

Figure S5. ${ }^{1} \mathrm{H}-{ }^{13} \mathrm{C}$ HSQC 2D NMR correlation spectroscopy of compound $1(400 \mathrm{MHz} / 100 \mathrm{MHz}, \mathrm{CDCl} 3)$. 


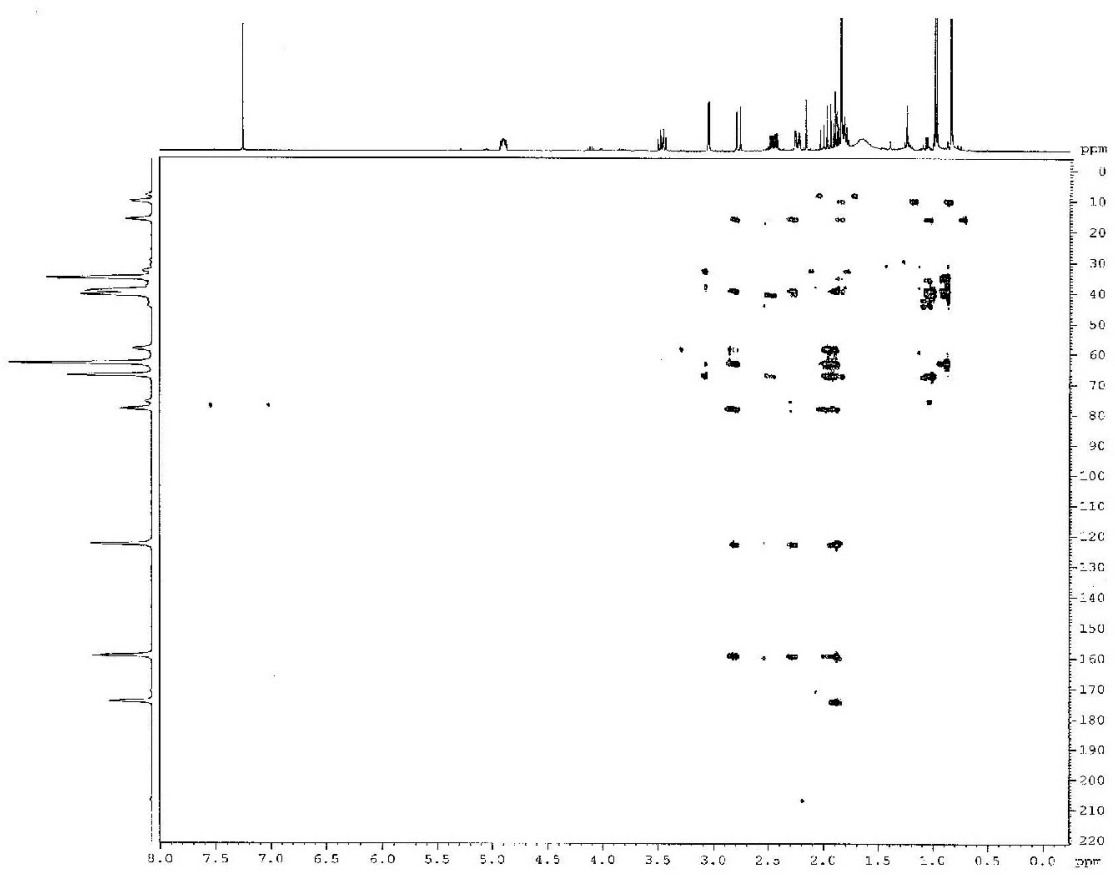

Figure S6. ${ }^{1} \mathrm{H}-{ }^{13} \mathrm{C}$ HMBC $2 \mathrm{D}$ NMR correlation spectroscopy of compound $1\left(400 \mathrm{MHz} / 100 \mathrm{MHz}, \mathrm{CDCl}_{3}\right)$.
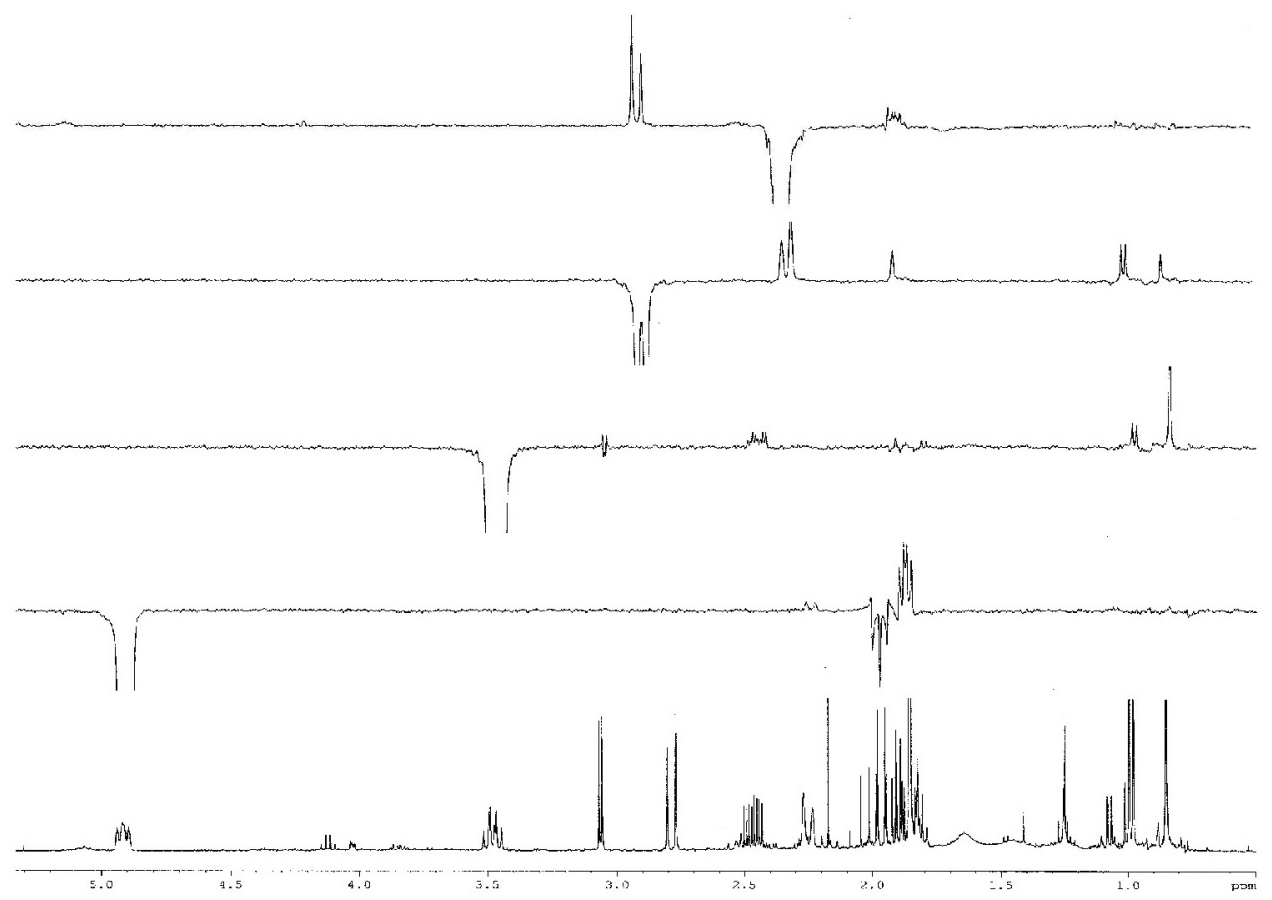

Figure S7. nOe spectra for H-8, H-3, H-6b and H-6a of compound 1 (400 MHz, $\mathrm{CDCl}_{3}$ ). 


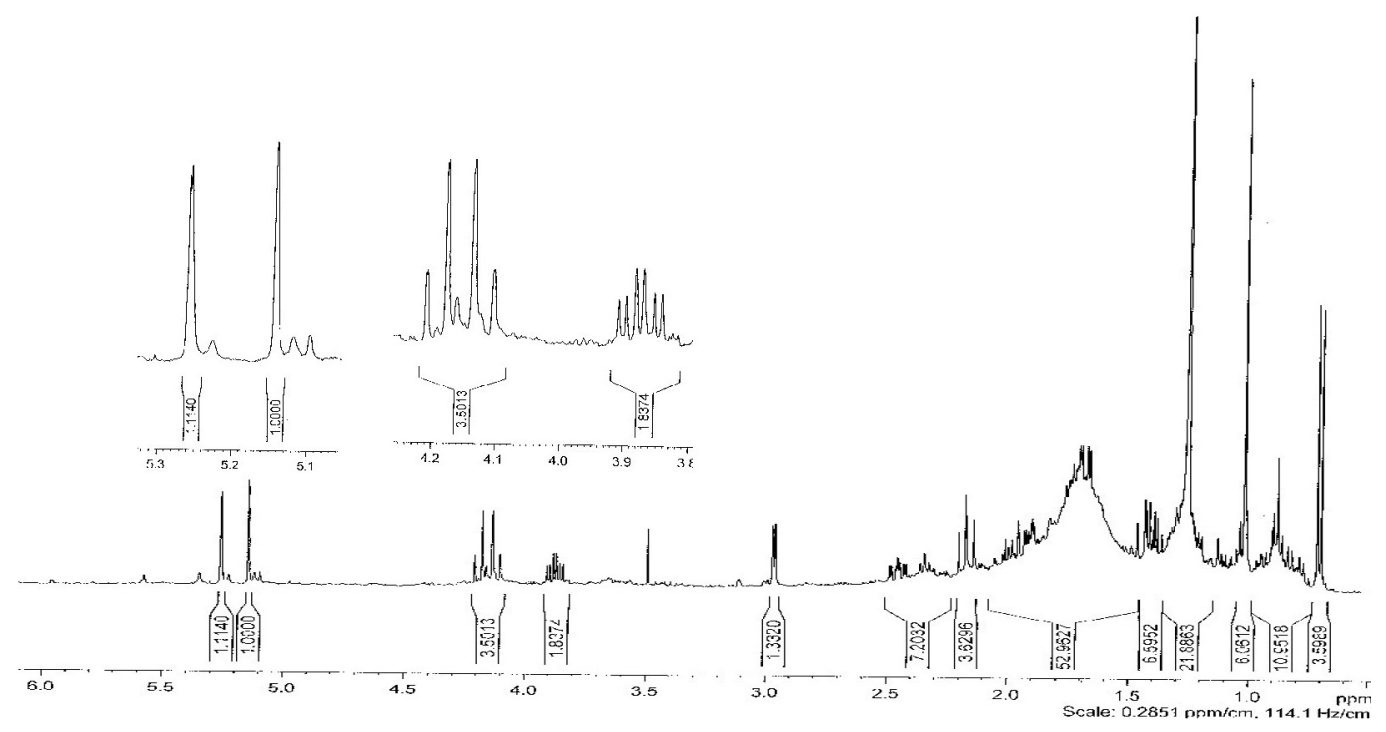

Figure S8. ${ }^{1} \mathrm{H}$ NMR spectrum of compound $2\left(400 \mathrm{MHz}, \mathrm{CDCl}_{3}\right)$.

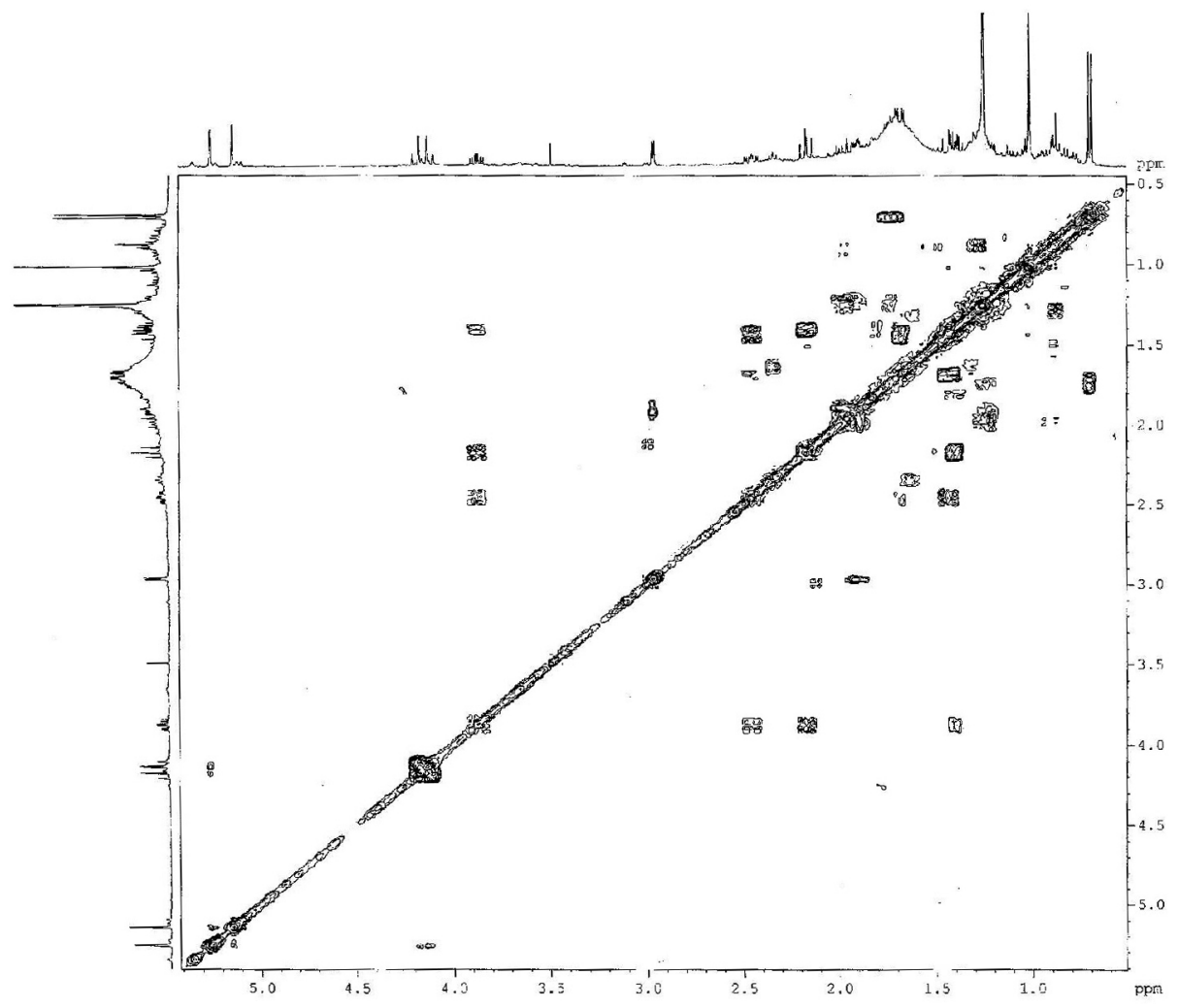

Figure S9. ${ }^{1} \mathrm{H}-{ }^{1} \mathrm{H}$ COSY NMR correlation spectroscopy $2 \mathrm{D}$ NMR spectrum of compound $2\left(400 \mathrm{MHz}, \mathrm{CDCl}_{3}\right.$ ). 


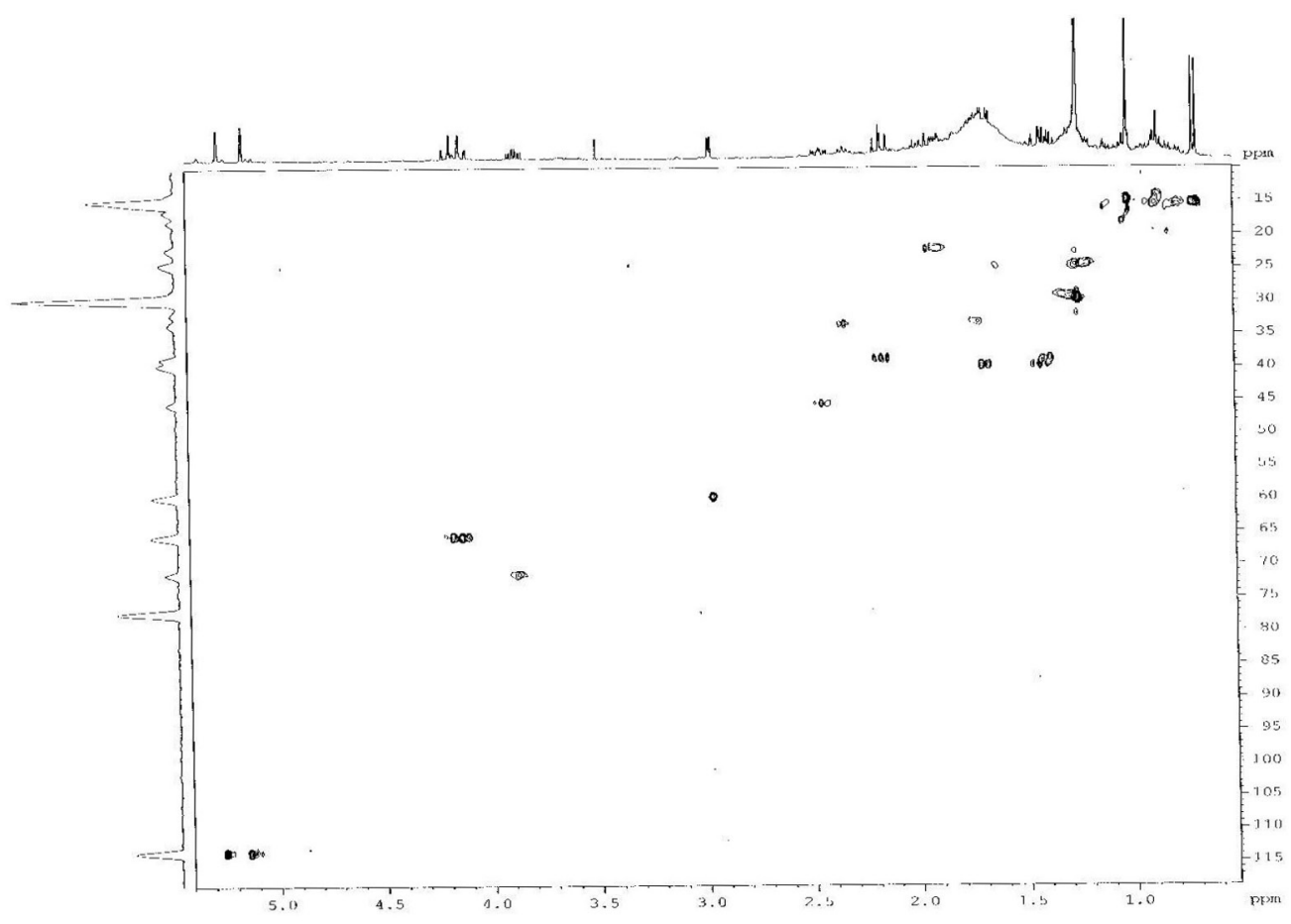

Figure S10. ${ }^{1} \mathrm{H}-{ }^{13} \mathrm{C}$ HSQC 2D NMR correlation spectroscopy of compound $2(400 \mathrm{MHz} / 100 \mathrm{MHz}, \mathrm{CDCl} 3)$.

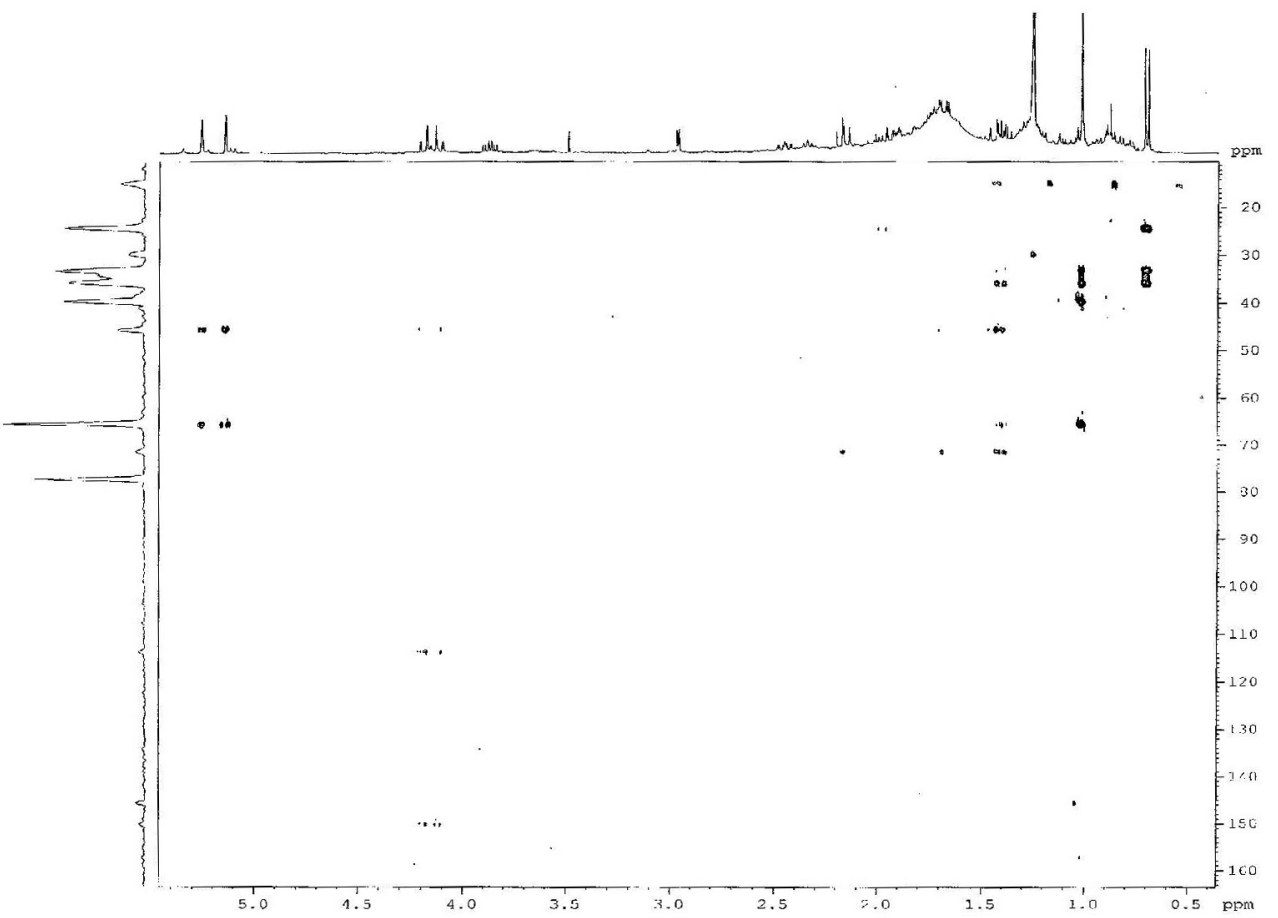

Figure S11. ${ }^{1} \mathrm{H}_{-}{ }^{13} \mathrm{C}$ HMBC $2 \mathrm{D}$ NMR correlation spectroscopy of compound $2\left(400 \mathrm{MHz} / 100 \mathrm{MHz}, \mathrm{CDCl}_{3}\right)$. 